\title{
動的風洞試験と飛行シミュレーションの連成に関する実験的研究*1 Experimental Study of Dynamic Wind Tunnel and Flight Simulator Coupling
}

\author{
宮 園 恒 平*2,*3 ·吉田健 太 ${ }^{* 2, * 4} \cdot$ 砂 田 保 人*2 ·今 村 太 郎*2 \\ Kohei Miyazono, Kenta Yoshida, Yasuto Sunada and Taro Imamura
}

Key Words : Dynamic Wind Tunnel Testing, Flight Simulation

\begin{abstract}
Dynamic wind tunnel testing is an important method to obtain aerodynamic characteristics of an aircraft. In this study, an experimental system for longitudinal dynamic force measurement is designed. A set of static and dynamic force measurement of a model aircraft is conducted using this system. Aerodynamic characteristics of the test model including dynamic stability coefficients were obtained from the results. Finally, dynamic wind tunnel system was coupled with $1 \mathrm{DoF}$ flight simulator. The amplitude and the frequency of the dynamic motion of the model aircraft was simulated successfully by the current system.
\end{abstract}

記号の説 明

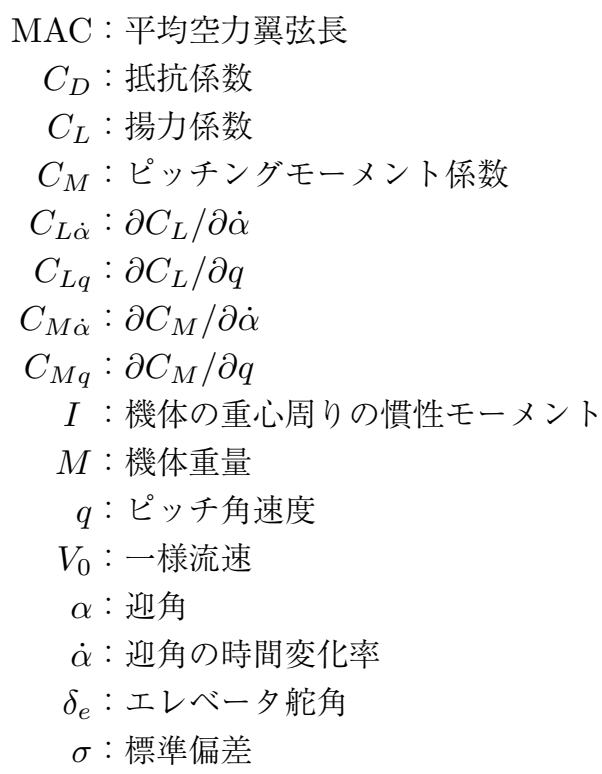

\section{1. は じめに}

航空機の飛行シミュレーションにおいては機体に作用す る空気力を計算する際に安定微係数を用いた線形空力モデ ルを利用する方法 ${ }^{1)}$ が一般的であり，風洞内で模型を運動 させて行う動的風洞試験は航空機の空力特性を同定するた めの手段として確立されている。例えば，米国 NASAの Langley 研究所では 1 自由度の強制運動型模型を用いた風

\footnotetext{
*1 (C) 2014 日本航空宇宙学会

平成 25 年 5 月 7 日原稿受付

*2 東京大学大学院工学系研究科航空宇宙工学専攻

*3 現川崎重工業

$* 4$ 現 本田技研工業
}

洞試験が実施されており, 様々な機体の動安定微係数デー 夕を取得している21. 日本においても，柳原3) は，通常の 航空機とは異なる形状を有する宇宙往還機の空力特性を推 定するため, 懸吊式風洞試験, 飛行試験, 並びに数值解析 を実施し, 線形空力モデルを構築することに成功している. しかしながら, 線形空力モデルは構築に多くのデー夕を必 要とし, また機体形状や飛行状態によっては空力特性が非 線形となり推算精度が低下することが知られている。この ような背景から, 欧州で進められている SUPRA プロジェ クト4,5)では, 航空機が異常姿勢に入った後の回復操縦方 法の確立に向けて, 非線形性を含めた航空機のシミュレー 夕開発が進められている。強制運動実験の結果をもとに非 線形空力モデルを作成しスピン風洞における自由飛行実験 でこのモデルの有効性を検証している．また Micro Aerial Vehicle (MAV) の場合には機速が遅く模型サイズも小さい ため, 機体に働く空気力の絶対值が小さく計測が困難であ るだけでなく, 剥離や失速が低レイノルズ数特有の流れ場 に支配され非線形性が強く表れることが知られている。こ のように, 航空機の非線形な運動の予測には課題があり, 飛 行シミュレーションにおいては非線形な空力モデルを取り 达むことが重要である。

そこで本研究では風洞実験で得られる空気力を直接飛行 シミュレーションと連成させることを目標とした動的風洞 試験実験装置を構築し, 実飛行を模擬した実験結果を得る ことを目的とする。新しい手法に対する研究であるため迎 角とエレベータ舵角のみを可変とした縦系の 1 自由度の装 置を用いて実験を行う。類似の試みとしては, 主翼のみの 単純な形状について滑空飛行軌道シミュレーションを実施 した Bacic ら 6) の先行研究がある. 空力特性は風洞実験か らリアルタイムで取得することにより飛行シミュレーショ ンを行ったが, 水平尾翼とエレベータを含む縦系について 
検討されていない，本研究では初めに模型を固定して，静 的に空力デー夕を取得する。続いて動的風洞試験より模型 迎角を変化させながら空力デー夕を取得し, 静的に取得し た空力データとの比較を行う. 最後に風洞実験データと飛 行シミュレーションとの連成実験を行う. 得られた結果よ り提案手法の実現性や取り組むべき課題を明らかにする。

\section{2. 実 験 装 置}

2.1 実験装置の概要 本研究で用いる実験装置の概要 を第 1 図に示す。実験模型は風洞に対して模型のピッチ角 を回転させるためにサーボモーターを介して支柱に取り付 けられている。また支柱とサーボモーターの間には 6 分力 天秤が設置されて㧍り，模型に作用する空気力を計測する ことができる.ささらに模型の胴体内部には別の小型サーボ モーターが設置されて扮り, 模型のエレベータ舵角を制御 することができる。 また風洞の動圧を差圧センサにより計 測することができる。

2.2 使用風洞 風洞は, 第 2 図に示す東京大学所有 のブローダウン式低速風洞を用いる。風洞の試験断面は $60 \mathrm{~cm} \times 60 \mathrm{~cm}$ であり，風速は $10 \mathrm{~m} / \mathrm{s}$ で使用する．風洞の 動圧を計測するための差圧センサとしてセンシリオン社製 SDP610を用いた。センサの入力は高圧側を風洞の絞り部 分の圧力, 低圧側を大気圧とし, 校正実験を行い実験で得 られた換算式によって測定部の動圧に変換した。

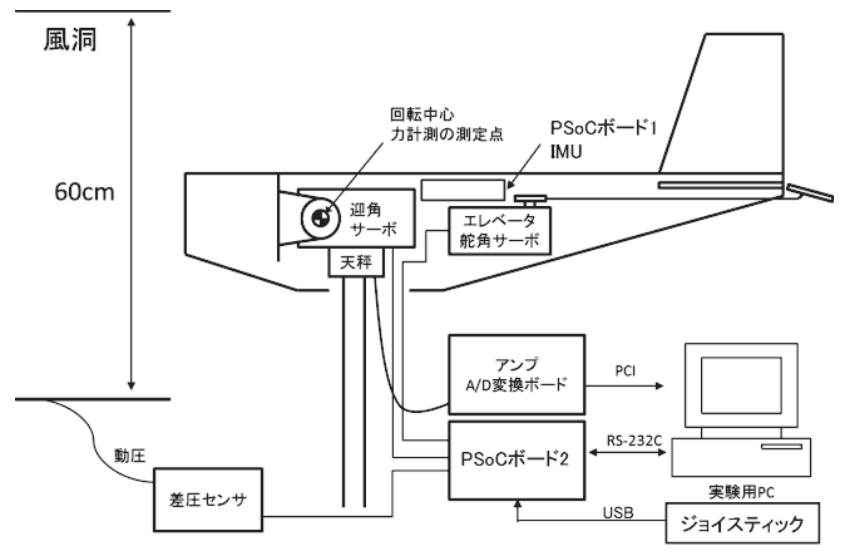

第 1 図 実験装置の概要

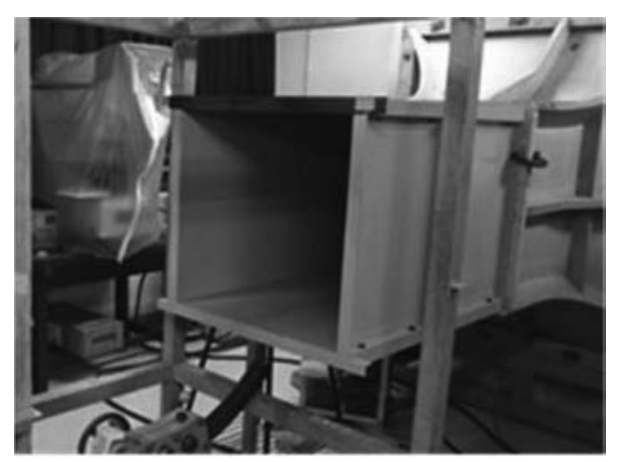

第 2 図 実験に使用する風洞
2.3 実験模型の設計 実験模型は風洞の試験断面のサ イズと後述する実験装置を収めるスペースを考慮してスパ ン $400 \mathrm{~mm}$ で設計し，木材を用いて製作した，写真と諸元 を第 3 図㧍よび第 1 表に示す.

2.4 天秤の選定と配置 力計測を行う上で最も重要と なるのが天科の選定と配置である。一般に多分力の計測を 行う際には軸間の干渉を抑えるため, 計測点の近くに天秤 を配置することが望ましい，本実験では計測点は模型の重 心位置であり, 迎角制御用サーボモーターの回転中心に一 致している. 従って天秤は模型の胴体内に納まる小型（直径 $17 \mathrm{~mm}$, 高さ $12 \mathrm{~mm}$ ) のものを選定した. 天秤の定格は模 型のサイズと風速から模型に作用する空気力を概算した結 果, 力の定格 $2.5[\mathrm{kgf}]$, モーメントの定格 $2[\mathrm{kgf} \cdot \mathrm{cm}]$ のも のを採用した，天秤を模型の内部に配置することにより測 定点と天秤の距離を最小化し軸間の干渉が抑えられるとと もに，支柱の下に天秤を設置した場合に必要となる支柱の 抗力補正が不要になるという利点が得られた (第 4 図参照).

2.5 迎角・舵角制御サーボ系 迎角制御には双葉電子工 業製のサーボモーターRS301CR を使用した，本製品は角 度検出センサとしてポテンショメータを内蔵しており, 簡 易的な角度制御が可能であるが，本実験では性能向上のた めセンサと制御系を改良したものを用いた，具体的にはま

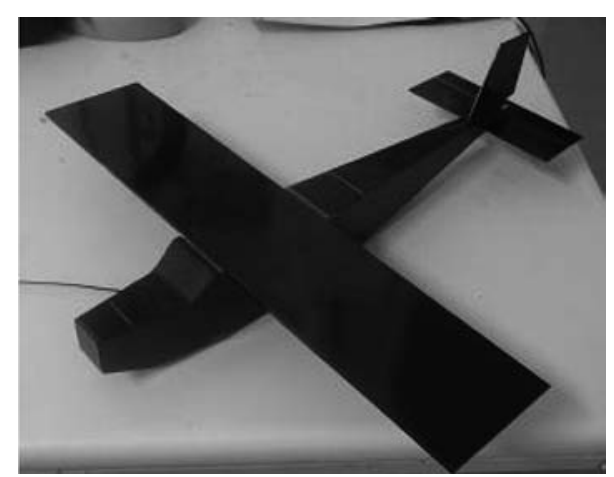

第 3 図 実験模型

\begin{tabular}{lc}
\multicolumn{1}{c}{ 第 1 表 } & 実験模型の設計 \\
\hline スパン & $400 \mathrm{~mm}$ \\
MAC & $80 \mathrm{~mm}$ \\
主翼面積 & $0.032\left[\mathrm{~m}^{2}\right]$ \\
翼型 & 平板 $($ 翼厚 $3.75 \%)$ \\
重心位置 & $35 \% \mathrm{MAC}$
\end{tabular}

重心位置 $35 \% \mathrm{MAC}$

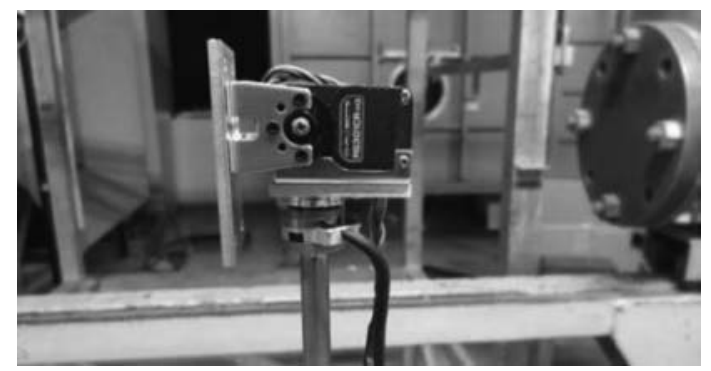

第 4 図 サーボモーターと天秤の配置 


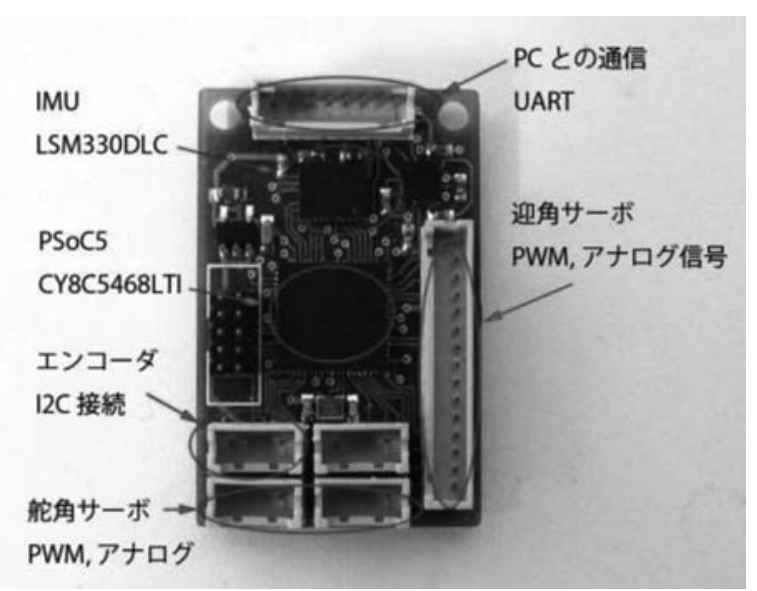

第 5 図 自作制御ボード

ず角度センサとしてノイズが大きいポテンショメータの代 わりに高精度な磁気エンコーダ7) を外付けした。また内蔵 コントローラでは角度の制御を $10[\mathrm{~ms}]$ 周期の比例制御の みで行っていたが, $1[\mathrm{~ms}]$ 周期で PI 制御を行うプログラム を自作し追従性を向上した。舵角の制御は胴体後部に設置 したラジコン用サーボを使用し，たわみ防止のためカーボ ンパイプに通した針金で舵面と接続した。

2.6 IMU と制御ボード 模型に作用する慣性力を計測 するため, 模型に IMU（慣性計測装置）を搭載した，本セ ンサはジャイロセンサと加速度センサが 1 つの IC に統合 されて㧍り 3 軸の角速度と加速度を検出可能である。 また IMU のセンサや前述のサーボモーターを統括, 制御し信号 入出力や PC との通信を行うため, 汎用性の高いマイクロ コントローラーである PSoC5 ${ }^{8}$ )を用いて制御ボード（第 5 図）を製作した。本ボードは模型の胴体内に搭載するため 小型化に努めた。

\section{3. 空 力 計 測}

3.1 迎角を一定に保持する静的計測 システム全体の 動作確認と模型の基本的な空力特性の確認のため, 迎角お よびエレベー夕舵角の指令值を一定の值で固定して計測を 行った，計測は，迎角は $-10 \sim 25[\mathrm{deg}]$ の範囲で 1 [deg] 間 隔，エレベータ舵角は $-10 \sim 10[\mathrm{deg}]$ の範囲で $2[\mathrm{deg}]$ 間隔 で行い， 1 点につき 10 秒間の平均を取った.

第 $6 \sim 8$ 図に得られた $C_{L^{-}}-\alpha, C_{D^{-}}-\alpha$ および $C_{M^{-}}-\alpha$ 曲線 を示す，それぞれのグラフには $\pm \sigma$ のエラーバーを付加し てあり, DATCOM ${ }^{9)}$ によって推算された曲線を重ねて描 いている。実験結果と DATCOM による推算結果は $\alpha<$ 10 [deg] の低迎角では一致しているものの， $\alpha>10$ [deg] で揚力傾斜が異なっており, ピッチングモーメントの傾き も変化している．また抗力も実験值の方が大きくなってい る. DATCOM では胴体を回転体で表現するが害際には実 験模型の胴体は長方形断面であるため, 胴体周りの流れ場 が異なることが影響している可能性が考えられる。

第 9 図に迎角 $0[\mathrm{deg}]$ に扔ける $C_{M}-\delta_{e}$ 曲線を示す．実験 結果と DATCOM および推算式1)を用いた推算結果とを比

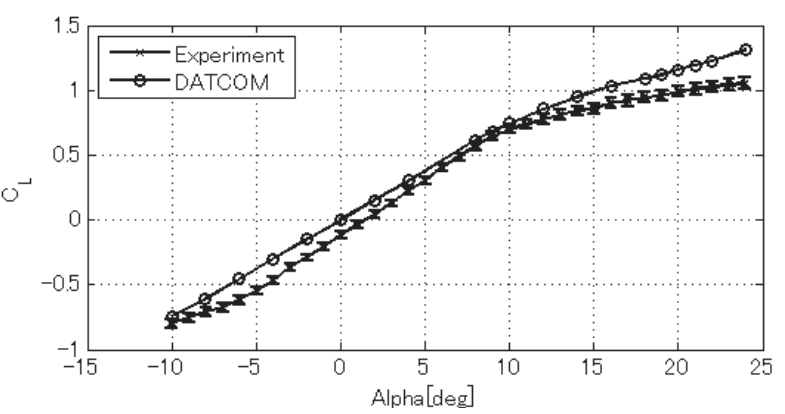

第 6 図 静的空力特性 $\left(C_{L}-\alpha\right)$

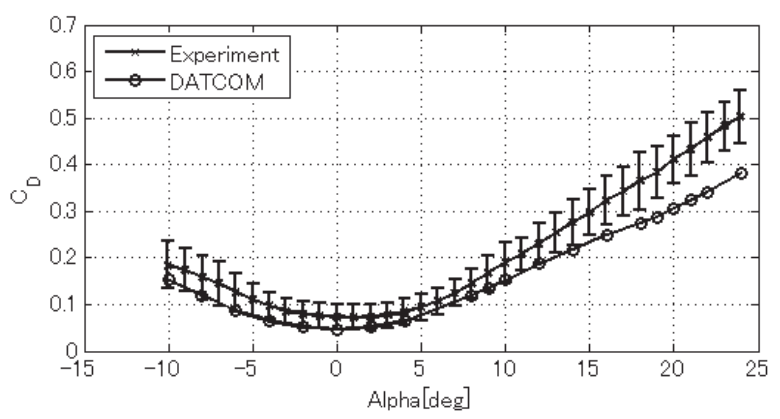

第 7 図 静的空力特性 $\left(C_{D^{-\alpha}}-\alpha\right)$

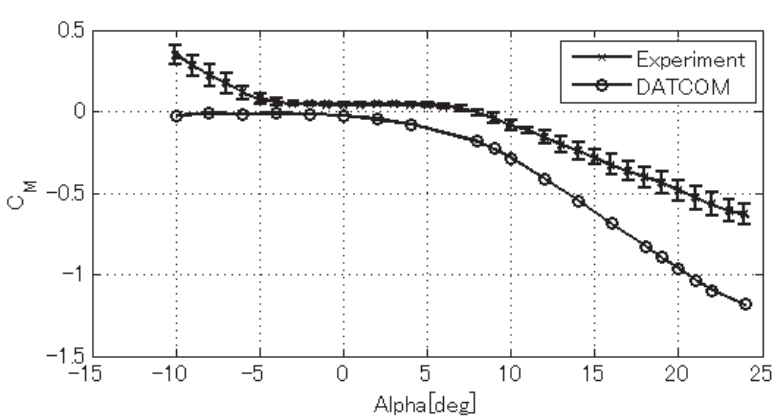

第 8 図 静的空力特性 $\left(C_{M}-\alpha\right)$

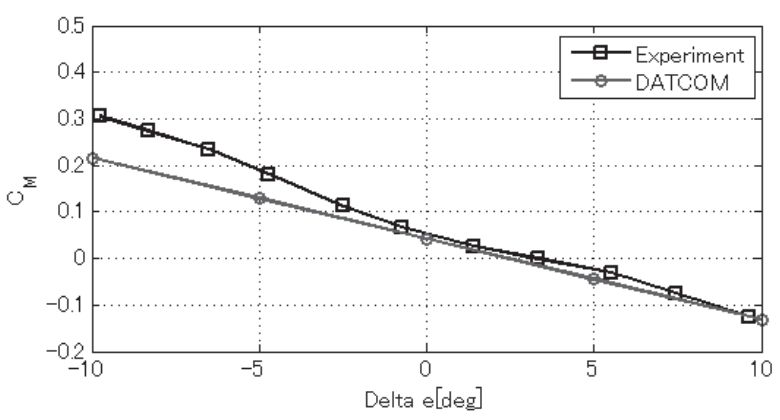

第 9 図 静的空力特性 $\left(C_{M}-\delta_{e}\right)$

較したところ，一致した結果が得られた。また，第 2 表に 示寸通り, 動安定微係数 $\left(C_{M \delta e}\right)$ も良好に一致した.

$3.2 \alpha$ スイープによる動的計測 次に迎角を連続的に 変化させながら計測を行った場合の結果を確認するため, 工 レベー夕舵角を一定に保ったまま，迎角をー10〜25 [deg] まで一定速度で連続的に変化 $(\alpha$ スイープ) させる指令值 を与え, 計測を行った。ヒステリシスの影響を見るため, 
第 2 表 動安定微係数の比較

\begin{tabular}{lccc}
\hline & 実験值 & DATCOM & 推算式1) \\
\hline$C_{M \delta e}[/ \mathrm{deg}]$ & -0.0221 & -0.0175 & -0.0258 \\
$C_{L \dot{\alpha}}+C_{L q}[/ \mathrm{deg} / \mathrm{s}]$ & 0.470 & 0.150 & 0.147 \\
$C_{M \dot{\alpha}}+C_{M q}[/ \mathrm{deg} / \mathrm{s}]$ & -0.353 & -0.430 & -0.467 \\
\hline
\end{tabular}

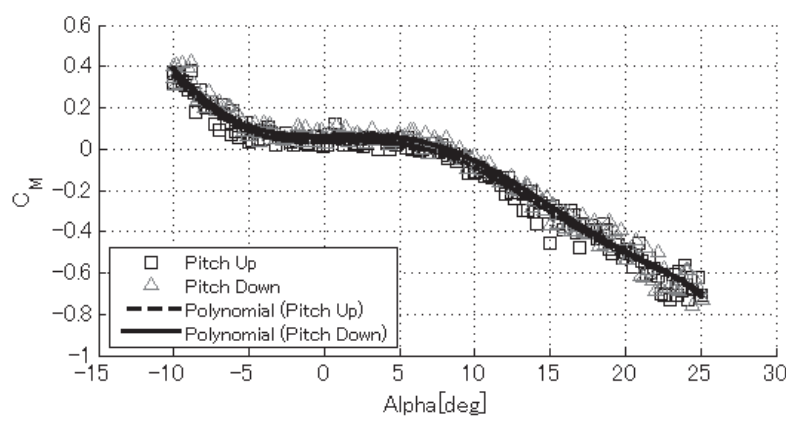

第10図 $\alpha$ スイープによる $C_{M^{-}} \alpha$ 特性 $(1[\mathrm{deg} / \mathrm{s}])$

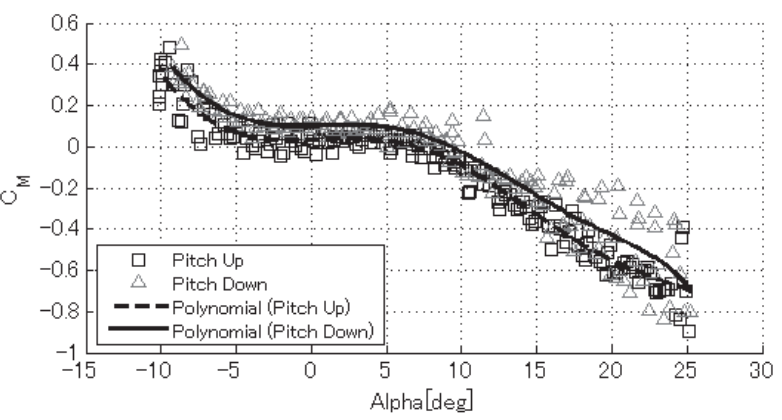

第11図 $\alpha$ スイープによる $C_{M}-\alpha$ 特性 $(20[\mathrm{deg} / \mathrm{s}])$

$-10[\mathrm{deg}]$ から開始して $25[\mathrm{deg}]$ まで頭上げ方向にスイー プし，その後 $-10[\mathrm{deg}]$ まで頭下げ方向にスイープして戻る 軌道を採用した。速度 $1.0[\mathrm{deg} / \mathrm{s}], 5.0[\mathrm{deg} / \mathrm{s}], 10.0[\mathrm{deg} / \mathrm{s}]$, $20.0[\mathrm{deg} / \mathrm{s}]$ のケースについて計測を行った， $\alpha$ スイープ試 験ではエレベータ舵角は $0[\mathrm{deg}]$ で一定とした。

第 10,11 図に迎角を $1.0[\mathrm{deg} / \mathrm{s}], 20.0[\mathrm{deg} / \mathrm{s}]$ の速度で スイープした結果を示す. 図中の $\square$ は頭上げ方向, $\triangle$ は頭 下げ方向の計測結果であり, 各方向について最小二乗法に より 6 次多項式で近似した曲線が重ねて示してある。また 第 12 図に静的計測の結果（エラーバー含む）と, $1[\mathrm{deg} / \mathrm{s}]$, $5[\mathrm{deg} / \mathrm{s}], \quad 10.0[\mathrm{deg} / \mathrm{s}], \quad 20[\mathrm{deg} / \mathrm{s}]$ の速度でのスイープ結 果を頭上げ，頭下げ方向を区別せずすべてのデータを用い て 6 次多項式で近似した曲線を重ねたグラフを示す。第 10 図の近似曲線は頭上げ方向と頭下げ方向で差が生じている。 スイープの角速度が速くなるに従い上下の曲線の差も拡大 していることから， 2 つの近似曲線の差分が迎角変化によ る動的な空気力を表していると仮定し，迎角 0 [deg]におけ る動安定微係数を求めた。この仮定は第 12 図で頭上げ, 頭 下げ両方の平均が静的計測の結果に一致していることから も妥当である。ただし本実験では模型の位置が風洞に対し て固定されているため迎角変化率 $\dot{\alpha}$ とピッチ角速度 $q$ は 同一であり， $\dot{\alpha}$ に対する微係数と $q$ に対する微係数を区別 することはできない，従って両者の和である

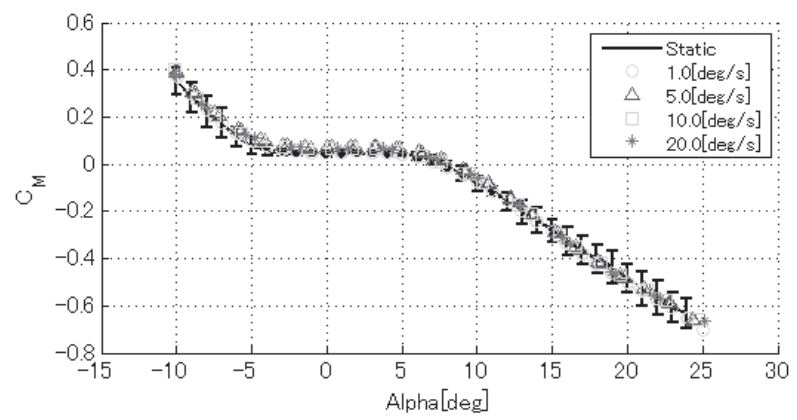

第12図 $\alpha$ スイープと静的計測による特性の比較

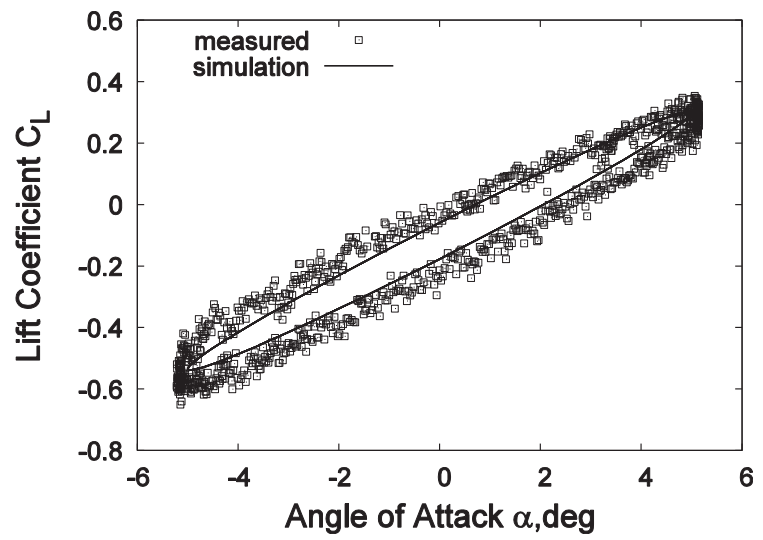

(a) $5.0[\mathrm{deg}], 1.0[\mathrm{~Hz}]$

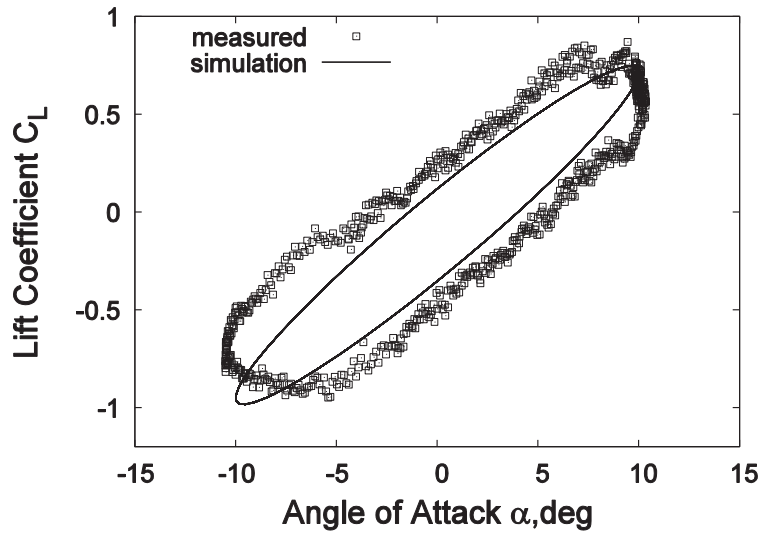

(b) $10.0[\mathrm{deg}], 2.0[\mathrm{~Hz}]$

第13 図 正弦波軌道による $C_{L}-\alpha$ 特性

$$
C_{L \dot{\alpha}}+C_{L q}, \quad C_{M \dot{\alpha}}+C_{M q}
$$

をそれぞれ求めた．DATCOM の值拈よび推算式 ${ }^{1)}$ と比較 した結果を第 2 表に示す、いずれも，符号とオーダーは一 致した。

3.3 正弦波軌道による動的空力計測 本研究の実験装 置を用いた動的な空気力計測についてさらに検証するため, 迎角の目標值として正弦波入力を用いた動的計測を行った。 目標軌道は迎角について振幅 $5.0[\mathrm{deg}], 10.0$ [deg], 周波数 $0.5,1.0,2.0[\mathrm{~Hz}]$ の計 6 通りについて実験を行った。取得 した力のデー夕に慣性補償を施した後, 空力倸数を求めた. 空力係数を迎角に対してプロットした結果，揚力とモーメ ントにはヒステリシスループが見られ，振幅，周波数が大 
きくなるに従ってループの囲む面積が大きくなる傾向が見 られた。振幅 5 [deg], 周波数 $1[\mathrm{~Hz}]$ と振幅 $10[\mathrm{deg}]$, 周波 数 $2[\mathrm{~Hz}]$ の場合について $C_{L}$ のループを第 13 図に示す. 第 6 図より迎角が $-5 \leq \alpha \leq 5$ の範囲で揚力係数の線形性が 仮定できるので，空気力に関する以下の線形回帰モデルを 使用したシミュレーション結果と比較する.

$$
\begin{aligned}
& C_{L}=C_{L 0}+C_{L \alpha} \alpha+\left(C_{L q}+C_{L \dot{\alpha}}\right) \frac{\bar{c}}{2 V_{0}} q, \\
& \alpha=\alpha_{0} \sin \omega t
\end{aligned}
$$

空力係数等は実験より $C_{L 0}=-0.1181, C_{L \alpha}=0.0833$, $C_{L \dot{\alpha}}+C_{L q}=0.470$ とした. いずれのケースでも時計回り に軌跡は動いている．振幅が $5.0[\mathrm{deg}]$ のケースにおいて実 験結果と良好な一致が見られ，10.0 [deg]のケースについて も定性的に一致した結果が得られた. 同様のヒステリシス ループは文献 10)における実験でも確認されており, 動的 な空力特性に起因すると考えられる. なお, フィル夕に関 しては天秤用アンプがカットオフ周波数 $100 \mathrm{~Hz}$ のローパ スフィルタを内蔵しており, その特性は 1 次遅れと推察さ れる。第 13 図の実験では入力周波数が $10 \mathrm{~Hz}$ 以下であり, またサンプリング周波数が $1 \mathrm{kHz}$ であることからエイリア シングの影響はないと考えられる。

\section{4. 運動方程式との連成}

以下では空力計測と 1 自由度の回転運動方程式のリアル タイム連成を試みた実験について述べる。

4.1 問題設定および実験方法 本実験では以下に述べ る系を模擬する。模型はピッチ角が变化する回転運動のみ 自由度を有し，並進運動は拘束されていると仮定する，従っ て模型の運動は 1 自由度の回転運動方程式で表され, 空気 力によるピッチングモーメントによって回転運動する。こ の問題設定は実飛行を想定したものではなく，あくまで空 力計測と運動方程式を連成させる簡単な例として考えたも のである。

実験の概要を第 14 図に示す。模型の運動の支配方程式は 1 自由度の回転運動方程式 $I \ddot{\alpha}=M$ である. 運動方程式を
解いてサーボの目標迎角を求める計算は $\mathrm{PC}$ 上で行う。 天 秤の出力はノイズを抑制するためローパスフィルタを通し て入力した．また慣性力をリアルタイムで補償する手法が 確立されていないため, 慣性力の影響が小さい低い入力周 波数で実験を行った。実験条件を第 3 表に示す.

4.2 シミュレーション＼cjkstart実験結果と比較するため, 4.1 節で述べた系のモデルを Simulinkによって作成し, シミュ レーションを行った。 シミュレーションでは空力計測の代 わりに事前に与えた空力モデルからモーメントを算出する. 模型の $C_{M \alpha}$ 特性は静的風洞実験の結果を線形補間した Lookup Tableによって再現し, 動安定微係数 $C_{M \dot{\alpha}}+C_{M q}$ については $\alpha$ スイープによって得られたー 0.353 を用いた. 舵角に対する特性は線形化し, 静的風洞実験の結果から $C_{M \delta e}=-0.0221$ とした.

4.3 結果 第 15 図にシミュレーションと実験によるエ レベータ舵角の入力と迎角応答の時系列データを示す. シ ミュレーションにおいては開始後およそ $2[\mathrm{~s}]$ で $C_{M}=0$ となる迎角 $7.4[\mathrm{deg}]$ に収束し, $t=5[\mathrm{~s}]$ でエレベータの操 舵が開始されると同時に迎角が一定の振幅で振動を開始し

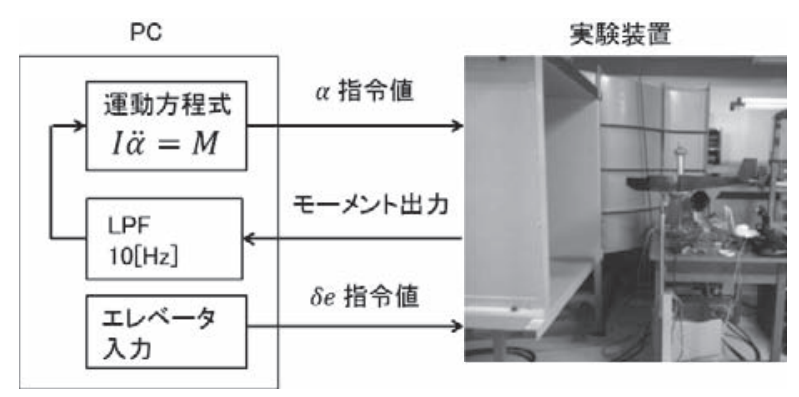

第 14 図 運動方程式と空力計測の連成

第 3 表 実験条件

初期条件 $[\mathrm{deg}],[\mathrm{deg} / \mathrm{s}] \quad \alpha=\dot{\alpha}=0$

慣性モーメント $\left[\mathrm{kgf} \cdot \mathrm{m}^{2}\right] \quad 0.001$

カットオフ周波数 $[\mathrm{Hz}] \quad 10$

入力 $\delta_{e}[\mathrm{deg}] \quad 0$

$0 \quad(t<5.0)$

$5.0 \sin (0.5 \times 2 \pi t) \quad(t>5.0)$

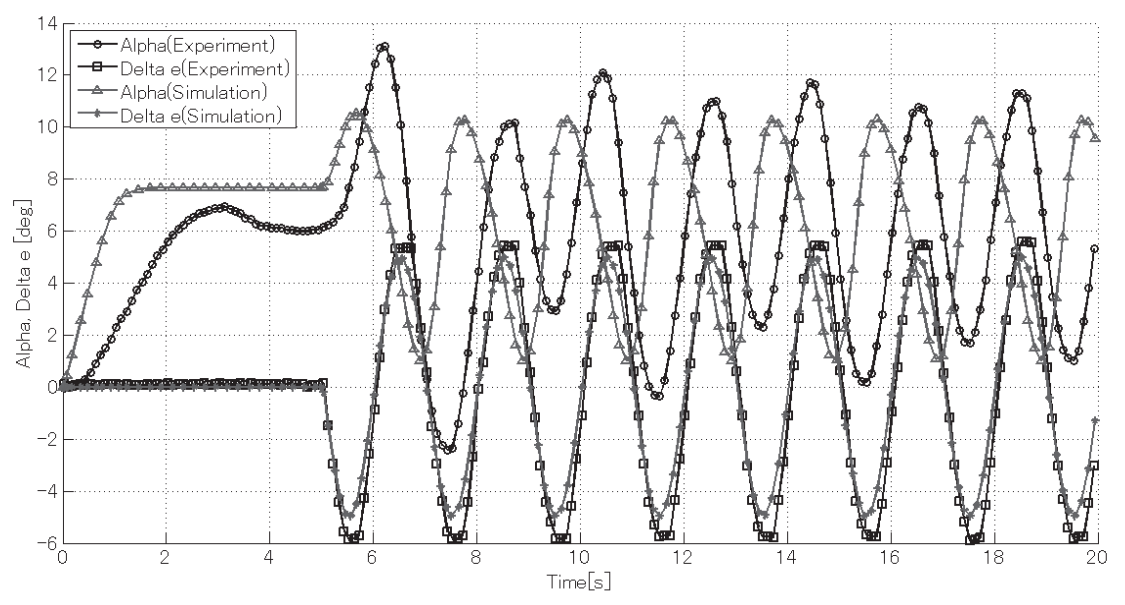

第 15 図運動方程式との連成実験の結果 
ている。一方で実験では第 15 図より実験開始後に迎角は緩 やかに $6[\mathrm{deg}]$ 付近に向かい, エレベータの正弦波入力が始 まると迎角も正弦波状の振動を開始するが, 実験結果はシ ミュレーションと比較して迎角の応答は位相が約 180 [deg] 遅れていることがわかる. シミュレーションでは模型の運 動は 1 自由度の回転運動方程式で表されると仮定している が，実験では迎角サーボ系の動特性が間に入るため，実験 結果において応答や位相が遅れることは妥当な結果である。 また天秤のノイズを抑制するローパスフィルタにも位相遅 れが存在するが, フィルタのカットオフ周波数 $10[\mathrm{~Hz}]$ に 比べて運動の周波数が $0.5[\mathrm{~Hz}]$ と小さいことからフィル夕 による位相遅れへの寄与は小さく, 本実験ではサーボ系に よる遅れが支配的であると考えられる。

動的風洞と運動方程式との連成を行うには応答が速く位 相遅れの小さいサーボ系を用いることが必要であるため, 本研究では 2.5 および 2.6 節で述べたようにエンコーダの 採用や制御回路の自作に取り組んできたが, より定量的に 一致したシミュレーション結果を得るには, さらなる性能 向上が必要なことを示している.

\section{5. 結 論}

本研究では飛行シミュレーションとの連成を目標として, 動的風洞試験の実験装置を構築し, 空力計測と運動方程式 の連成実験を行った。以下では本研究によって得られた知 見を順に述べる。

実験装置の構築にあたっては，天秤の配置，計測機器の 配置等で改良を重ね，計測精度の向上に努めた。また迎角 サーボモーターの角度検出とトルク制御に関しては外付け のエンコーダと自作の制御回路を追加することにより検出 精度，サーボの応答性を向上させることができた。

その結果, 静的空力計測に関しては静的な縦 3 分力の迎 角, 舵角に対する特性について DATCOM と整合性のある 結果を導くことができ, 実験模型の基礎的な空力特性を確 認するとともに実験装置の動作確認を行うことができた.

$\alpha$ スイープ動的空力計測に関しては, 迎角を連続的に変 化させながら縦 3 分力を計測し, 実験結果から動安定微係 数を導出した. 得られた動安定微係数は DATCOM や推算 式による值と符号とオーダーが一致した。正弦波軌道によ る動的空力計測では, 揚力とモーメントにはヒステリシス
ループが見られ, 振幅, 周波数が大きくなるに従ってルー プの囲む面積が大きくなる傾向が見られた．また線形回帰 モデルを用いたシミュレーション結果と一致する結果が得 られた。

最後に運動方程式との連成実験では空気力のモーメント によってピッチ軸に関して回転運動する系を模擬した実験 とシミュレーションを行った。振幅や周期等に関して，定 性的に一致した結果が得られたが, サーボの位相遅れに関 しては課題が明らかになった。

以下では今後の課題について述べる。迎角制御サーボ系 に関してはさらなる性能向上が必要である。目標としてい るシミュレーションと風洞試験の連成ではサーボ系は任意 の運動を遅れなしに再現できることが前提となっており, サーボ系は応答が高速で位相遅れが小さいことや目標軌道 に正確に追従することが求められる. 動的風洞のように外 乱が大きい環境でそれを実現するには, 例えば空気力を推 算してフィードフォワードで補償するといった, 空気力学 と制御工学の両面からのアプローチが求められると考えら れる。本報では簡単な系を考えたため運動として迎角変化 のみを扱ったが, 将来的には上下の並進運動, さらには横 方向系の運動を加える拡張にも取り組んでいきたい.

\section{参 考 文 献}

1) 加藤寛一郎 : 航空機力学入門, 東京大学出版会, 東京, 1982 .

2) Vicroy, D. D., Loeser, T. D. and Schütte, A.: Static and Forced-Oscillation Tests of a Generic Unmanned Combat Air Vehicle, J. Aircraft, 49, 6 (2012), pp. 1558-1583.

3) 柳原正明 : 宇宙往還機形状の空力特性推定のための飛行試験法に 関する研究，東京大学博士論文，2007.

4) Khrabrov, A., Sidoryuk, M. and Goman, M.: Aerodynamic Model Development and Simulation of Airliner Spin for Upset Recovery, Progress in Flight Physics, Vol. 5, EDP Sciences, Les Ulis, France, 2013, pp. 621-636.

5) Simulation of Upset Recovery in Aviation, http://www. supra.aero/home.htm

6) Bacic, M. and MacDiarmid, M.: Hardware-in-the-Loop Simulation of Aerodynamic Objects, AIAA Paper 2007-6465, 2007.

7) Austria Microsystems, AS5048A/AS048B Datasheet.

8) Cypress Semiconductors PSoC5 CY8C55 Family Datasheet.

9) Datcom+ Pro User's Manual, http://www.holycows.net/

10) Hoe, G., Owens, D. B. and Denham, C.: Forced Oscillation Wind Tunnel Testing for FASER Flight Research Aircraft, AIAA Paper 2012-4645, 2012. 